\title{
Analyzing Internal Migration to Antalya and Muğla through Gravity Modelling'
}

\author{
Ali T. AKARCA (https://orcid.org/0000-0003-1411-1695), Department of Economics, University of Illinois at \\ Chicago,U.S.A.; e-mail: akarca@uic.edu \\ Aysit TANSEL (https://orcid.org/0000-0001-9556-2396), Department of Economics, Middle East Technical \\ University, Turkey; Institute for Study of Labor (IZA), Germany; Economic Research Forum (ERF), Egypt; e- \\ mail:atansel@metu.edu.tr
}

\section{Antalya ve Muğla'ya olan İç Göçün Çekim Modeli ile Analizi²}

\begin{abstract}
Antalya and Muğla provinces located in southwestern Turkey recently emerged as new magnets for internal migration. In an earlier study, we had pointed out that the dynamics underlying migration to these two provinces differs in many respects from that fueling the population movements to traditional magnets. In this paper, we complement our previous findings by showing how in some other key respects, migration to Antalya and Muğla is similar to migration to traditional destinations. We accomplish this by estimating separate gravity models for the two provinces in question, using both OLS and robust regression methods. We find that migration to Antalya and Muğla is affected by distance from the origin adversely, and by unemployment differential between the origin and destination, past migration from the origin, population sizes at the origin and destination, and natural disasters at the origin, favorably.
\end{abstract}

Keywords

Internal Migration, Labor Market, Gravity Model, Turkey, Antalya, Muğla.

JEL Classification Codes : J21, J61, R23.

\section{$\ddot{\mathbf{O z}}$}

Türkiye'nin güneybatısında yer alan Antalya ve Muğla illeri son zamanlarda iç göç için birer mıknatıs haline geldiler. Daha önce yaptığımız bir araştırmada, bu illere göçü doğuran dinamiklerin, pek çok bakımdan, iç göçü geleneksel mekânlara çeken dinamiklerden farklı olduğuna dikkat çekmiştik. Bu çalışmada ise başka önemli yönlerden, Antalya ve Muğla'ya olan göçün geleneksel merkezlere olan göç ile ne kadar benzer olduğunu göstererek önceki bulgularımızı tamamlıyoruz. Bunu, EKK ve Robust regresyon metodları kullanarak, bahsi geçen her iki il için ayrı birer çekim (gravity) modeli saptayarak gerçekleştiriyoruz. Bulgularımıza göre, Antalya ve Muğlaya olan göç, çıkış noktasına olan uzaklık arttıkça olumsuz, çıkıs noktası ile varış noktası işsizlik oranları arasındaki fark, çıkiş noktasından alınmış geçmiş göç, çıkış ve varış noktalarının nüfusları ve çıkış noktasında meydana gelen afetlerin büyüklüğü arttıç̧a olumlu etkilenmektedir.

1 We thank two anonymous reviewers of this journal for their valuable suggestions which improved the paper substantially.

2 Bu derginin iki anonim hakemine makalemizi önemli ölçüde geliştiren değerli onerileri için teşekkür ederiz. 
Anahtar Sözcükler I Iç Göç, İşǘcü Piyasası, Çekim Modeli, Türkiye, Antalya, Muğla.

\section{Introduction}

Recently, Antalya and Muğla, two adjacent provinces in southwestern Turkey, emerged as new magnets for internal migration. In an earlier paper (Akarca \& Tansel, 2017) we showed that migration to these provinces differ in many aspects from that towards traditional magnets. The aim of the present study is to complement the findings of that paper by showing how, in some key respects, factors fueling migration to the two provinces in question and to other destinations are similar. This will be accomplished through a gravity model.

The gravity model is quite popular among researchers of migration for very good reasons. In the words of Poot, et al. (2016) "for at least half a century, and building on observations first made a century earlier, the gravity model has been the most commonlyused paradigm for understanding gross migration flows between regions. This model owes its success to, firstly, its intuitive consistency with migration theories; secondly, ease of estimation in its simplest form; and, thirdly, goodness of fit in most applications." Some of the notable studies which discuss and/or apply this model include Dhar (1984), Mueser (1989), Greenwood (1997), Lucas (1997), Andrienko and Guriev (2004), Fan (2005), Phan and Coxhead (2010), Etzo (2011), Aldashev and Dietz (2012), Buena (2012), Pacheco, Rossouw and Lewer (2013), and Amara and Jemmali (2017). Although there are many studies on internal migration in Turkey, for example, Munro (1974), Gedik (1996), Tunalı (1996), Pazarlığlu (1997), Gündüz and Yetim (1997), İçduygu and Ünalan (1998), Gezici and Keskin (2005), Kocaman (2008), and Filiztekin and Gökhan (2008), only the last one employed the gravity model. None of them focused specifically on migration flows to Antalya and Muğla, and they all treated migration flows to different destinations as if they are similar. We hope to gain more insight by studying migrant flows to the two provinces in question separately.

The outline of the paper is as follows. Next section presents the gravity model and typical pull and push factors it includes. Specific variables considered for the case at hand are also discussed in that section. Our results obtained from fitting this model to data are given in Section 3. Then in Section 4, the conclusions we have reached are listed.

\section{The Gravity Model}

In view of a number of good surveys of the migration literature and the gravity model (for example, Poot et al., 2016; Anderson, 2011; Etzo, 2008; Greenwood \& Hunt, 2003), we will not provide here yet another survey but briefly explain what the model involves. According to the basic gravity model, the flow of migrants between two locations is a function of the populations of the two locations, and the distance, previous migration and unemployment (or wage) rate differentials between them. It is assumed that the number of people leaving or arriving at a location will be higher the larger is its population. Immigration 
is seen as an economic activity with its costs and benefits spread over time. Benefits are assumed to be higher for those moving from a high unemployment (low wage) area to a low unemployment (high wage) area. The current unemployment rate or earnings are taken as proxies for future employment possibilities and earnings. The distance between the origin and the destination is treated as a proxy for the cost of moving. The latter is assumed to include the psychic costs of removal from loved ones, a familiar culture and environment, and costs of information acquisition, besides the transportation costs. The presence of friends, family and other contacts already at the destination as a result of past migration is also relevant, as it tends to lower the costs of information acquisition, settling at the new location, and being away from loved ones, and raise the probability of finding a job at the destination.

The top fifteen migrant sending provinces to Antalya and Muğla are shown in the map given in Figure 1. This map confirms the importance of the factors the gravity model emphasizes. The fact that three most populous provinces in Turkey (İstanbul, Ankara and İzmir) generate the highest proportions of migrants to the two destinations in question (collectively more than a fourth) suggests that population size may be an important determinant. That ten of the top fifteen migrant generating provinces are clustered around the migrants' destinations may be interpreted as distance being a key variable as well. Six of the fifteen provinces shaded in Figure 1are among the fifteen provinces with the highest unemployment rates in the country. Thus high unemployment appears as yet another important factor motivating migration to the southwest.

Four of the six provinces with the highest unemployment rates (İstanbul, Ankara, Diyarbakır and Van) are far away from Antalya and Muğla, implying that a desire to find a job may outweigh the effect of distance. However there are other provinces with even higher unemployment rates and which are closer. Yet they do not send many migrants to the two provinces in question. Fourteen provinces lying between Syrian and Iraqi borders and a line drawn from the northwestern border of Mersin and Adana to the northeastern border of Van and Iran, together with İstanbul, Ankara and İzmir, capture all of the provinces with unemployment rates exceeding 10.5 percent in 2000. Among them only four are distant to Antalya and Muğla and at the same time among the top migrant originators to the two provinces. Thus, other factors besides high unemployment must be at play. What differentiates the four provinces (İstanbul, Ankara, Diyarbakır and Van) from the rest is the fact that they are among those with substantial past migration to Antalya and Muğla. As we mentioned above, the existence of friends, family and other acquaintances already at the destination, tends to lower costs of moving and increases the chances of landing a job. These are referred to as "kinship" or "network" effects in the literature. Fourteen of the fifteen provinces shaded in Figure 1 are among the twenty-three provinces (out of 79) with the highest proportions of fellow-townsmen in Antalya and Muğla. So this factor is important as well. In the case of Kocaeli, the only one of the fifteen provinces missing from the list of top twenty-three fellow-townsmen origins, two major earthquakes which hit it in 1999 was the main reason for high out-migration. 
In the basic gravity model, it is assumed that the influences of population, distance, past immigration and unemployment differential would be the same for all migration flows. We will include in our model all of these variables but we will fit separate equations for Antalya and Muğla and allow the parameter values to differ between the two equations. Typically, in empirical applications, in addition to the variables mentioned, other pull and push factors are considered as well. We did as well. However, all of the additional variables we tried, except one, provided unsatisfactory results. The exceptional variable was the one representing the intensity of the damage caused by the two earthquakes which devastated nine provinces in $1999 .{ }^{3}$ Loss of their businesses and/or homes may have hastened the decisions of those contemplating migrating, and may have pushed those who became fearful of a similar disaster in the future to relocate. Also, many of the survivors who were evacuated temporarily to hotels in Antalya and Muğla which are largely unoccupied during winter months, may have decided to settle at these locations permanently. We have added a variable to the basic model to capture the earthquake factor.

Other factors we considered included the age distribution (median age), level of education (mean years of schooling), rate of urbanization, climate (average temperatures prevailing during the coldest and warmest months), at the origin relative to that at the destination, and the size of the originating province (its radius, computed under the assumption that the province has a circular shape). However, none of these made a statistically significant contribution. The median age was considered because young migrants can expect a longer stream of wage differentials and stand to gain more from a move. The information acquisition and adjustment to a new environment should be easier and cheaper for the educated people and consequently should lead to higher emigration from provinces with higher mean years of schooling. That was the motivation behind trying the latter variable. Unfortunately, with macro data it was not possible to measure effects of these variables separately because they are correlated with each other and with the unemployment variable already in the equations. Where unemployment rate is high, usually the median age and the education level are low. Urbanization level was considered because the extra urban amenities, such as health care and educational opportunities, gained by people moving from less urbanized areas are likely to be more. The idea behind the use of radius is that smaller localities are likely to have larger out-migration because it takes a shorter move to get out of the province than in larger provinces. Antalya and Muğla have very pleasant climates, which attract many tourists, domestic and foreign. The climactic variables were considered to check whether some of the permanent moves to this area are motivated by weather related factors.

The final model we arrived at is the following:

3 The nine provinces, all located in the northwestern region of Turkey, are the following: Bolu, Bursa, Düzce, Eskişehir, İstanbul, Kocaeli, Sakarya, Zonguldak and Yalova. 


$$
\begin{aligned}
& \ln \mathrm{M}_{\mathrm{ij}}=\mathrm{a}_{\mathrm{j}}+\mathrm{b}_{\mathrm{j}} \ln \mathrm{P}_{\mathrm{j}}+\mathrm{c}_{\mathrm{j}} \ln \mathrm{D}_{\mathrm{ij}}+\mathrm{f}_{\mathrm{j}} \ln \left(\mathrm{U}_{\mathrm{i}} / \mathrm{U}_{\mathrm{j}}\right)+\mathrm{g}_{\mathrm{j}} \ln \mathrm{H}_{\mathrm{ij}}+\mathrm{n}_{\mathrm{j}} \ln \mathrm{Q}_{\mathrm{i}}+\mathrm{e}_{\mathrm{ij}} \quad \mathrm{i}=1,2,3, \ldots, 79 \\
& \mathrm{j}=80 \text { and } 81
\end{aligned}
$$

where
$\mathrm{M}_{\mathrm{ij}}$ : number of people who migrated from province $\mathrm{i}$ to province $\mathrm{j}$, between 1995 and 2000,
$\mathrm{P}_{\mathrm{i}}$ : resident population of province $\mathrm{i}$ in 1995 ,
$\mathrm{D}_{\mathrm{ij}}$ : highway distance (in kilometers) between the capital cities of provinces $\mathrm{i}$ and $\mathrm{j}$,
$\mathrm{U}_{\mathrm{i}}$ : unemployment rate in province $\mathrm{i}$,
$\mathrm{H}_{\mathrm{ij}}$ : number of people residing in province $\mathrm{j}$ in 1995 who were born in province $\mathrm{i}$,
$\mathrm{Q}_{\mathrm{i}}$ : number of residences and businesses in province $\mathrm{i}$ which suffered heavy damage in 1999 earthquakes,
$e_{i j}$ : the disturbance term for province $i$ in the equation for $j$,

and $a_{j}, b_{j}, c_{j}, f_{j}, g_{j}$, and $n_{j}(j=80,81)$ are parameters to be estimated. $j$ is equal to 80 for Antalya and 81 for Muğla. All variables are measured in logarithms, as it is typically done in applications of the gravity model. Destination population is not in the equation as it would be the same for all observations. Thus its effect is incorporated into the constant.

\section{Empirical Results}

The above equations are estimated first using Ordinary Least Squares (OLS) method, results of which are presented in the first two columns of Table 1. Sources of data utilized is given in the notes to the table. All of the parameters in the table are statistically significant and the R-square values for the two equations are 0.93 and 0.87 . So the gravity model fits the data quite well. However, large differences exist between the two equations in case of some parameter estimates, which are hard to explain. Also, some outliers were spotted. These may be caused by factors specific to particular origins which are ignored. To make sure that such outliers did not contaminate our results, we estimated the equations also with the robust regression procedure introduced by Rousseeuw (1984) and developed further by Rousseeuw and Van Driessen (2000) and Zaman et al. (2001). The last two columns of table 1 present those. Indeed, the procedure identifies nine outliers for Antalya equation and two for Muğla, which are listed in the notes of the table. ${ }^{4}$ When these are taken into account, cross-equation differences between the parameter values narrows to sensible levels and R-

4 In case of these provinces other pull and/or push factors must be at play which need to be studied further but this is beyond the aim of the current study. 
square values increase. We will base our analysis on the robust regressions which are more reliable given the circumstances.

Because the variables in the equations are in logarithms, the parameters can be interpreted as elasticities. According to the estimation results, a percentage increase in the population of the origin is expected to result in 0.52 percent more migration to Antalya and 0.60 percent more to Muğla. Constant coefficient being positive for Antalya and negative and insignificant for Muğla may indicate the former attracting more migrants due to its relatively larger population. One percent increase in the distance of a province to the two provinces in question, on the other hand, causes 0.63 and 0.41 percent drop, respectively, in the number of migrants. A percent increase in the unemployment rate of a province (relative to that prevailing at the destination), leads to a 0.45 and 0.33 percent increase in the migration flows, respectively. It appears that a smaller incentive is required to entice a migrant to Antalya than to Muğla, and cost is less of a deterrent for migration to the former than to the latter. These may have to do with Antalya offering more urban amenities than Muğla, as a result of being relatively more populous.

Migration from one location to another leads to more migration in the future. Existence of fellow-townsmen from a particular province seem to have the same effect on the migration from that province to both Antalya and Muğla. One percent increase in the number of people from an origin living in southwestern Turkey generates $0.38-0.39$ percent more migration from that province. Likewise, it appears that the 1999 earthquakes have increased the migration from the provinces impacted to Antalya and Muğla in similar proportions. Each percentage increase in the number of residences and businesses which suffered heavy quake damage in a province, translated into a little less than 0.02 percent increase in migration to Antalya and Muğla. Even though this is quite small, not including this variable in the migration equations would have biased the other results.

\section{Summary and Conclusion}

Two provinces in southwestern Turkey, Antalya and Muğla, recently emerged as new internal migration magnets. Akarca and Tansel (2017) demonstrated that these provinces and the population flows to them have different characteristics than the traditional migrant magnets and migration towards them. However, in some key respects, migration to Antalya and Muğla and to other destinations are similar. More specifically, desire to find a job or a better job is the main motivation behind migration, immigrants from earlier eras living at a destination triggers more migration there, distance is a strong hindrance to migration, but large populations at the origin and destination encourage migration. In these four regards, migration to southwestern Turkey is not different from migration to traditional destinations. It appears that the 1999 earthquakes which occurred in northwestern Turkey, caused the migration from that region to be higher as well.

\section{References}

Akarca, A.T. \& A. Tansel (2017), "Tourism Driven Migration to Southwestern Turkey”, Boğaziçi Journal Review of Social, Economic and Administrative Studies, 31(1), 23-42. 
Aldashev, A. \& B. Dietz (2012), "Economic and spatial determinants of interregional migration in Kazakhstan”, IZA Discussion Paper No. 6289.

Amara, M. \& H. Jemmali (2017), "Deciphering the Relationship between Internal Migration and Regional Disparities in Tunisia", Social Indicators Research, forthcoming.

Anderson, J.E. (2011), “The gravity model”, The Annual Review of Economics, 3(1), 133-160.

Andrienko, Y. \& S. Guriev (2004), "Determinants of inter-regional mobility in Russia”, Economics of Transition, 12(1), 1-27.

Buena, D. (2012), "Modern gravity models of internal migration: The case of Romania", Theoretical and Applied Economics, Vol. 19, 127-144.

Dhar, S. (1984), "Inter-state and within-state migration in India", in: Contractual Arrangements, Employment and Wages in Rural Labor Markets in Asia, H.P. Binswanger \& M.R.

Rosenzweig (eds), Economic Growth Center, Yale University, 281-304.

Etzo, I. (2011), "The determinants of recent interregional migration flows in Italy: A panel data analysis", Journal of Regional Science, Vol. 51, 948-966.

Etzo, I. (2008), "Internal migration: A review of the literature", MPRA Working Paper No. 8783.

Fan, C.C. (2005), "Modeling interprovincial migration in China 1985-2000", Eurasian Geography and Economics, 46(3), 165-184.

Filiztekin, A. \& A. Gökhan (2008), “The determinants of internal migration in Turkey”, paper presented at International Conference on Policy Modelling (EcoMod2008), Berlin, Germany, 2-4 July 2008.

Gedik, A. (1996), "Internal migration in Turkey, 1965-85: Test of some conflicting findings in the literature", Working Paper in Demography No. 66, Austrian National University, Canberra, Australia.

Gezici, F. \& B. Keskin (2005), "Interactions between regional inequalities and internal migration in Turkey", paper presented at the $45^{\text {th }}$ Congress of the European Regional Science Association: Land Use and Water Management in a Sustainable Network Society, Amsterdam, 23-27 August 2005.

Greenwood, M.J. \& G.L. Hunt (2003), “The early history of migration research”, International Regional Science Review, 26(1), 3-37.

Greenwood, M.J. (1997), “Internal migration in developed countries”, in: M.R. Rosenzweig \& O. Stark (eds.), Handbook of Population and Family Economics, Vol. 1B, Elsevier, Amsterdam, 647-720.

Gündüz, M. \& N. Yetim (1997), “Terör ve Göç”, (Terrorism and migration) in: Toplum ve Göç-II. Ulusal Sosyoloji Kongresi (November 20-22, 1996, Mersin) Bildiriler Kitabi, SIS Pub. Number 2046, Ankara, SIS, 109-118.

İçduygu, A. \& T. Ünalan (1998), “Türkiye'de iç göç: Sorunsal alanları ve araştırma yöntemleri”, (Internal migration in Turkey: Its problem areas and research methods) in: Türkiye'de $\dot{I}_{c ̧}$ Göç, Sorunsal Alanlart ve Araştırma Yöntemleri Konferansı (June 6-8, 1998, BoluGerede) Bildiriler Kitabı, İstanbul: Türkiye Ekonomik ve Toplumsal Tarih Vakfi, 38-55.

Kocaman, T. (2008), Türkiye'de Iç Göçler ve Göç Edenlerin Nitelikleri: 1965-2000 (Internal migration in Turkey and the characteristics of those who migrate: 1965-2000), Ankara: State Planning Organization, Prime Ministry, the Republic of Turkey. 
Lucas, R.E.B. (1997), “Internal migration in developing countries”, in: M.R. Rosenzweig \& O. Stark (eds.), Handbook of Population and Family Economics, Volume 1B, Elsevier, Amsterdam, 721-798.

Mueser, P. (1989), "The spatial structure of migration: an analysis of flows between states in the USA over three decades", Regional Studies, 23(3), 185-200.

Munro, J. (1974), "Migration in Turkey”, Economic Development and Cultural Change, 22(4), 63453.

Pacheco, G.A. \& S. Rossouw \& J. Lewer (2013), "Do Non-Economic Quality of Life Factors Drive Immigration?", Social Indicators Research, 110(1), 1-15.

Pazarlığlu, M.V. (1997), “1980-1990 döneminde Türkiye’de iç göç üzerine ekonometrik model çalışması", (An Econometric model study on internal migration in Turkey for the period 1980-1990) Çukurova University V. National Econometrics and Statistics Symposium, Adana.

Phan, D. \& I. Coxhead (2010), “Inter-provincial migration and inequality during Vietnam's transition", Journal of Development Economics, 91(1), 100-112.

Poot, J. \& O. Alimi \& M.P. Cameron \& D.C. Maré (2016), “The Gravity Model of Migration: The Successful Comeback of an Ageing Superstar in Regional Science”, IZA Discussion Paper No. 10329.

Rousseeuw, P.J. (1984), “Least Median of Squares Regression”, Journal of the American Statistical Association, 79(388), 871-880.

Rousseeuw, P.J. \& K. Van Driessen (2000), “An Algorithm for Positive-Breakdown Regression Based on Concentration Steps”, in: W. Gaul \& O. Opitz \& M. Schader (eds.), Data Analysis: Scientific Modeling and Practical Application, New York: Springer-Verlag, 335-346.

SAS (2008), SAS/STAT 9.2 User's Guide, Cary, North Carolina: SAS Institute Inc.

Tunal1, İ. (1996), "Migration and remigration of male household heads in Turkey, 1963-1973", Economic Development and Cultural Change, 45(1), 56-67.

Zaman, A. \& P.J. Rousseeuw \& M. Orhan (2001), "Econometric Applications of High-Breakdown Robust Regression Techniques”, Econometrics Letters, 71(1), 1-8. 


\section{Figure: 1}

\section{Origins of Immigrants in Antalya+Muğla (1995-2000)}

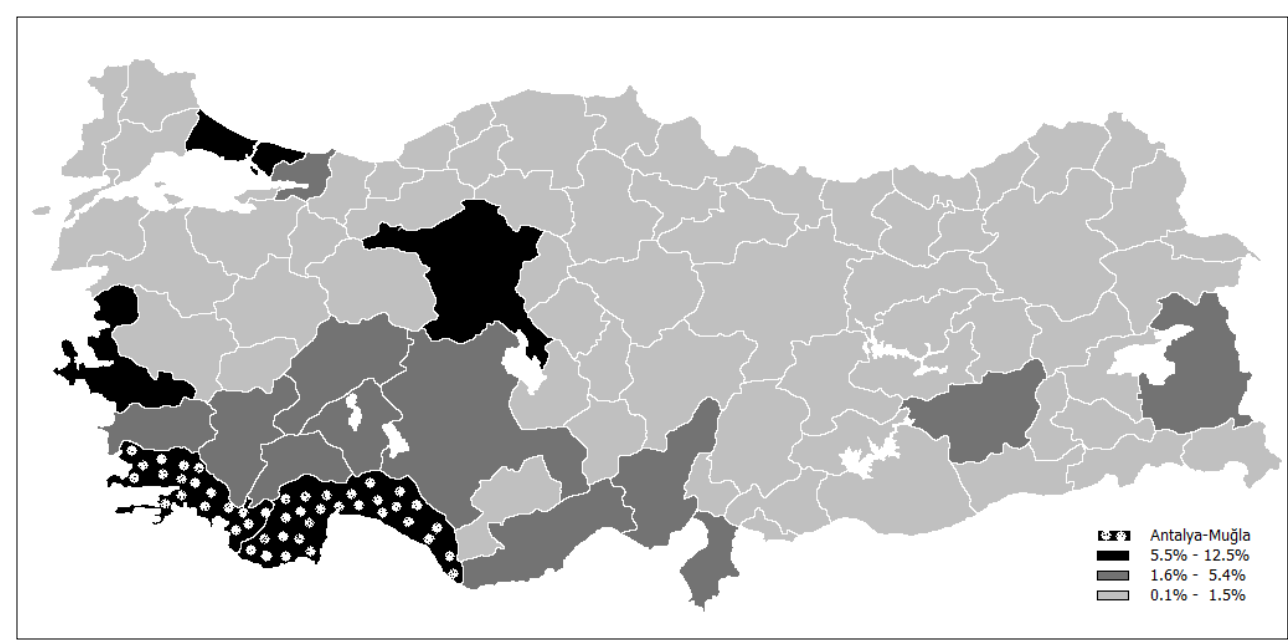

Notes: Migration from the province to Antalya+ Muğla between 1995 and 2000, in proportion to total in-migration to the latter during the same period.

Source: Turkish Statistical Institute (Prime Ministry, the Republic of Turkey). 
Table: 1

Estimated Regression Equations

\begin{tabular}{|c|c|c|c|c|}
\hline \multirow{2}{*}{ Variables } & \multicolumn{2}{|c|}{ OLS Regressions } & \multicolumn{2}{|c|}{ Robust Regressions } \\
\hline & ANTALYA & MUĞLA & ANTALYA & MUĞLA \\
\hline CONSTANT & $\begin{array}{c}1.730 \\
(0.057)\end{array}$ & $\begin{array}{c}-2.236 \\
(0.073)\end{array}$ & $\begin{array}{l}1.454 \\
(0.03)\end{array}$ & $\begin{array}{c}-1.508 \\
(0.149)\end{array}$ \\
\hline RESIDENT POPULATION & $\begin{array}{c}0.486 \\
(0.000)\end{array}$ & $\begin{array}{c}0.883 \\
(0.000)\end{array}$ & $\begin{array}{c}0.521 \\
(0.000)\end{array}$ & $\begin{array}{c}0.605 \\
(0.000)\end{array}$ \\
\hline DISTANCE & $\begin{array}{c}-0.610 \\
(0.000)\end{array}$ & $\begin{array}{c}-0.493 \\
(0.000)\end{array}$ & $\begin{array}{c}-0.626 \\
(0.000)\end{array}$ & $\begin{array}{c}-0.408 \\
(0.000)\end{array}$ \\
\hline RELATIVE UNEMPLOYMENT & $\begin{array}{c}0.454 \\
(0.000)\end{array}$ & $\begin{array}{c}0.281 \\
(0.065)\end{array}$ & $\begin{array}{c}0.448 \\
(0.000)\end{array}$ & $\begin{array}{c}0.326 \\
(0.010)\end{array}$ \\
\hline PAST MIGRATION & $\begin{array}{c}0.420 \\
(0.000)\end{array}$ & $\begin{array}{c}0.037 \\
(0.064)\end{array}$ & $\begin{array}{c}0.392 \\
(0.000)\end{array}$ & $\begin{array}{c}0.378 \\
(0.000)\end{array}$ \\
\hline EARTHQUAKE & $\begin{array}{c}0.026 \\
(0.000)\end{array}$ & $\begin{array}{c}0.013 \\
(0.045)\end{array}$ & $\begin{array}{c}0.018 \\
(0.000)\end{array}$ & $\begin{array}{c}0.017 \\
(0.003)\end{array}$ \\
\hline $\mathrm{R}^{2}$ & 0.93 & 0.87 & 0.96 & 0.92 \\
\hline
\end{tabular}

Notes: All variables are in logarithms. For definitions of variables, see Section 3. The dependent variable in each regression is the number of people who migrated from province $i$ to province $j$ (Antalya or Muğla) during 19952000 (Mij). The OLS (Ordinary Least Squares) regressions are estimated, utilizing the REG procedure of SAS (2008) statistical package. Robust regressions are estimated using the same statistical package's ROBUSTREG procedure with the LTS (least trimmed squares) method and FWLS (final weighted least squares) option. The following observations are picked by the latter algorithm as outliers: Ankara, Bolu, Giresun, Hatay, Kahraman Maraș, Tunceli, Van and Yalova, in the Antalya equation, and Hakkari and Kocaeli in the Muğla equation. The numbers in parantheses below the parameter estimates are the probabilities relevant to the t-test of whether the associated coefficient is equal to zero, in the case of first two columns, and to the corresponding chi-square test in the case of last two columns.

Source: The data on the EARTHQUAKE (Qi) variable is obtained from the General Directorate of Disaster Affairs (Ministry of Public Works and Settlement, the Republic of Turkey). The DISTANCE (Dij) values are taken from the General Directorate of Highways (Ministry of Transport and Communication, the Republic of Turkey). The source of data for all other variables is the Turkish Statistical Institute (Prime Ministry, the Republic of Turkey). The RESIDENT POPULATION in 1995 (Pi) figures are obtained by deducting from the resident population of province $i$ in 2000, the total in-migration into the province, and adding total out-migration from the province during 1995 2000. To approximate the PAST MIGRATION (Hij) figures, which are not readily available, the product of Mij and the proportion of native born in province $i$ is deducted from the number of people living in province $j$ in 2000 who were born in province $i$. In a few cases where the resulting figure turned out to be negative, it is taken as 0.000001 instead. The latter is not given the value of zero, so that logarithms can be taken. For the same reason, for those provinces not affected by the 1999 earthquakes, Qi is taken as 0.000001 rather than zero. 